\title{
PATTERNS OF ANTIHYPERTENSIVE DRUGS' USE IN COMMUNITY PHARMACY; DRUG RELATED PROBLEMS AND ADHERENCE TO MEDICATION IDENTIFIED IN A RETROSPECTIVE ANALYSIS OF PRESCRIPTIONS
}

\author{
CRISTINA DANIELA MARINECI ${ }^{1}$, CRISTINA ELENA ZBÂRCEA ${ }^{1}$, EMIL ȘTEFĂNESCU ${ }^{1}$, \\ ALINA CRENGUȚA NICOLAE ${ }^{2}$, CĂTĂLINA ANCUȚA GIREA ${ }^{3}$, CORNEL CHIRIȚA ${ }^{1}{ }^{1 *}$, \\ SIMONA NEGRES ${ }^{1}$
}

\author{
1 "Carol Davila” University of Medicine and Pharmacy, Faculty of Pharmacy, Department of Pharmacology and Clinical \\ Pharmacy, Bucharest, Romania \\ 2 "Carol Davila" University of Medicine and Pharmacy, Faculty of Pharmacy, Department of Biochemistry, Bucharest, Romania \\ ${ }^{3}$ Oncology Institute Professor Doctor Alexandru Trestioreanu, Department of Pharmacy, Bucharest, Romania
}

*corresponding author: chirita.cornel@gmail.com

Manuscript received: May 2020

\begin{abstract}
Despite effective antihypertensive medication, arterial hypertension remains an important contributor to cardiovascular diseases, the main global cause of mortality. We performed a retrospective analysis of prescriptions containing antihypertensive drugs dispensed from two community pharmacies from Bucharest, Romania. In order to explore differences in prescriptions' trends, we analysed drugs dispensed in 2007 and 2017, evaluating the frequencies of the drugs used in monotherapy or in poly-therapy and the conformity with treatment guidelines available at the moment, the drug related problems and patients' adherence to medication, based on the superposition of drugs prescribed and those dispensed. We analysed 4635 prescriptions, from which 2332 were presenting at least HBP as diagnostic. 52.05\% of the 2198 prescriptions from 2017 were for HBP, statistically significant compared to the $48.75 \%$ of the 2537 corresponding prescriptions from 2007. All the main antihypertensive drugs classes increased statistically significant in use from 2007 to 2017, except the angiotensin-converting enzyme inhibitors. Antihypertensive monotherapy decreased from $27.8 \%$ in 2007 to $19.7 \%$ in 2017 (p < 0.0001), which was in line with the updated recommendations that favoured combination therapy as being more efficacious. As to the drug regimen complexity, $11.5 \%$ of the prescriptions from 2007 and $18.6 \%$ of the prescriptions from 2017 contained antihypertensive drugs prescribed in a different manner from the one indicated in their officially endorsed monographs. We also found that in $2007,10.94 \%$ of hypertensive patients didn't purchase all the medicines prescribed by the doctor, giving up part of their treatment. In 2017, the percentage of these nonadherent patients raised to $20.19 \%$. We believe that pharmacist's interventions, including suggestions for simplification of the drug regimen, can increase the levels of adherence to medication, thus improving hypertensive patients' clinical outcomes.
\end{abstract}

\section{Rezumat}

Deși medicația antihipertensivă este eficientă, hipertensiunea arterială (HTA) are o contribuție importantă la principala cauză de mortalitate la nivel global, bolile cardiovasculare. Am realizat o analiză retrospectivă a prescripțiilor destinate HTA, prescripții eliberate din două farmacii de comunitate din București, în perioade din doi ani diferiți (2007 și 2017), pentru a evalua tendințele de prescriere și utilizare a medicamentelor antihipertensive. Am determinat frecvențele generale de utilizare ale diferitelor antihipertensive atât în contextul monoterapiei cât şi în cazul asocierilor, conformitatea cu ghidurile de tratament antihipertensiv în vigoare la momentele respective, problemele de terapie medicamentoasă și aderența pacienților la medicație, bazată pe concordanța dintre medicamentele prescrise și cele eliberate. Am analizat 4635 de prescripții, dintre care 2332 au avut cel puțin HTA ca diagnostic. 52,05\% dintre cele 2198 de rețete din 2017 au fost pentru HTA, semnificativ statistic mai mult decât procentul prescripțiilor similare din 2007 (48,75\% din 2537 de rețete). Toate principalele clase de antihipertensive au crescut în utilizare între 2007 și 2017, semnificativ statistic, cu excepția inhibitorilor enzimei de con versie a angiotensinei. Monoterapia antihipertensivă a scăzut ca utilizare, de la 27,8\% în 2007, la 19,7\% în 2017 (p < 0,0001), tendinţă în acord cu recomandările actualizate ale ghidurilor de tratament, care favorizează terapiile combinate ca fiind mai eficiente. În ceea ce privește complexitatea regimului medicamentos, am descoperit că $11,5 \%$ din prescripțiile din 2007 și 18,6\% din cele din 2017 au conținut medicamente antihipertensive prescrise într-o altă manieră decât cea recomandată în monografiile lor oficiale. În 2007, 10,94\% dintre pacienții hipertensivi nu și-au ridicat integral medicaţia prescrisă, renunțând la o parte din tratament; în 2017, procentul acestor pacienți non-aderenți a crescut la 20,19\%. Considerăm că intervențiile farmacistului, printre care sugestiile de simplificare a regimului medicamentos, pot crește nivelurile de aderență a pacienți lor hipertensivi la medicaţie, și astfel îmbunătăţirea rezultatele clinice ale acestora.

Keywords: antihypertensive drugs', prescription patterns, drug related problems, adherence to medication 


\section{Introduction}

Worldwide, World Health Organization (WHO) estimates that 1.13 billion people have hypertension [28], whereas in Romania, general hypertension prevalence is $45.1 \%$ [10].

Despite the real progress made in the last decades in antihypertensive drugs launched into therapy and accumulated knowledge about their optimal usage, high blood pressure remains one of the most important contributors to the morbidity and mortality due to cardiovascular causes. WHO states that less than 1 in 5 hypertensive persons have the problem under control [28]. Low levels of adherence to medication might be one of the reasons of suboptimal antihypertensive outcomes [4].

In 2003 the European Society of Hypertension and the European Society of Cardiology issued their first specific guideline on hypertension, dedicated to European countries, which acknowledged not only relevant randomized controlled trials, meta-analyses or large observational studies, but also the particularities of the European population, namely greater longevity, higher incidence of chronic cardiovascular disease and higher economic status [12]. In 2007 [17] and in 2013 [18] new and updated Guidelines for management of hypertension were launched, in an attempt to offer the best available and most balanced practical recommendations, for the best clinical outcomes of individual patients, who may differ widely in their personal, medical and cultural characteristics.

Those documents highlighted the non-adherence to medication, which is a drug-related problem (DRP). A DRP is any unintended event implying medication therapy, and negatively affecting the patient, interfering actually or potentially with the desired outcomes of therapy; pharmaceutical judgement is required in order to solve these problems $[6,22]$. Low adherence to medication is an important DRP [6, 22], some of whose determinants are modifiable by the pharmacist's intervention [21] (e.g. adherence to medications decreases as the number of daily doses increases [15], so drug regimen simplification could result in a better adherence). The aims of our study were to identify and analyse changes in the usage of antihypertensive drugs in Romanian outpatients, as reflected by medicines dispensed by two community pharmacies during the same three months periods of two different years (2007 and 2017). We were interested in the differences in frequencies of prescriptions of particular drugs, but also in the combinations of drugs used. We were interested in investigating the prescriptions' conformities with treatment guidelines (The national recommendations [5] and the ESH-ESC Guidelines for the management of arterial hypertension [12, 18] available at the moment).

We analysed the prescriptions in order to identify the drugs related problems, especially the ones related to regimen complexity. We also quantified patients' adherence to medication, based on the superposition of drugs prescribed and those dispensed. Non-adherence to antihypertensive drugs reaches significant levels in Romanian patients, as previous studies revealed $[19,24]$.

\section{Materials and Methods}

We conducted a retrospective analysis of prescriptions containing antihypertensive drugs dispensed from two community pharmacies from Bucharest, Romania, in the same three months of 2007 and 2017 (April, May, June).

From all the prescriptions containing reimbursed medications dispensed in these 2 periods, the prescriptions having as diagnostic HBP were included in the analysis. The following data were extracted: all the diagnostics affecting the patient, the medication prescribed and dispensed. Regarding medication, data of interest were the names of the drugs (international non-proprietary name (INN) or proprietary name in case of fixed combination), posology (daily dose, frequency of administration) and number of unitary doses prescribed and dispensed.

For each year, we determined and compared: antihypertensive medications used (we classified them into proper pharmacological classes, and then compared the classes); type of therapy (monotherapy consisting in one antihypertensive drug used, bi-therapy consisting in two antihypertensive drugs used as different medicinal product or in fixed combination and so on); inaccurate posology, such as too many daily doses (for example, we retained as a DRP the written indication of administration twice or thrice a day for a drug whose official prescribing information recommends it once daily; those situations not necessary exceeded the maximum allowed daily dose, but they increased the number of daily drugs taken by the patient); prescriptions of drugs partially dispensed. In these situations, the patients were considered non-adherent, because they did not follow the doctor's indications, purchasing and taking less medication.

Compliance with ethical standards

Research and publications ethical standards were observed. The procedures that we used were in accordance with the national ethical standards of clinical studies and with the Declaration of Helsinki (1975), as revised in 2000.

Statistical analysis

The statistical analysis was performed using IBM SPSS Statistics 23 for Windows and Microsoft Excel for Mac, version 16.27. The differences in percentages were assessed using $\chi^{2}$ test, at a significance level of $\mathrm{p}<0.05$. 


\section{Results and Discussion}

We analysed 4635 prescriptions, from which 2332 were presenting HBP as diagnostic. 52.05\% of the 2198 prescriptions from 2017 were for HBP, statistically significantly more compared to the $48.75 \%$ of the 2537 corresponding prescriptions from 2007.

Therapeutic classes' usage

We observed statistically significant differences ( $\mathrm{p}<$ 0.0001 , unless otherwise specified) between the use of the following classes of antihypertensive drugs in 2007 and 2017 (Figure 1).
The decline in angiotensin-converting-enzyme (ACE) inhibitors' use could be explained by the rise in angiotensin II receptor blockers' (ARBs) use. The very good tolerability of ARBs, beside their antihypertensive efficacy and evidence-based benefits in heart failure and diabetic renal disease made ARBs to increase in use [1]

In accordance with the treatment guidelines for hypertension [12, 17], we noticed an increase in the use of diuretics in antihypertensive therapy.

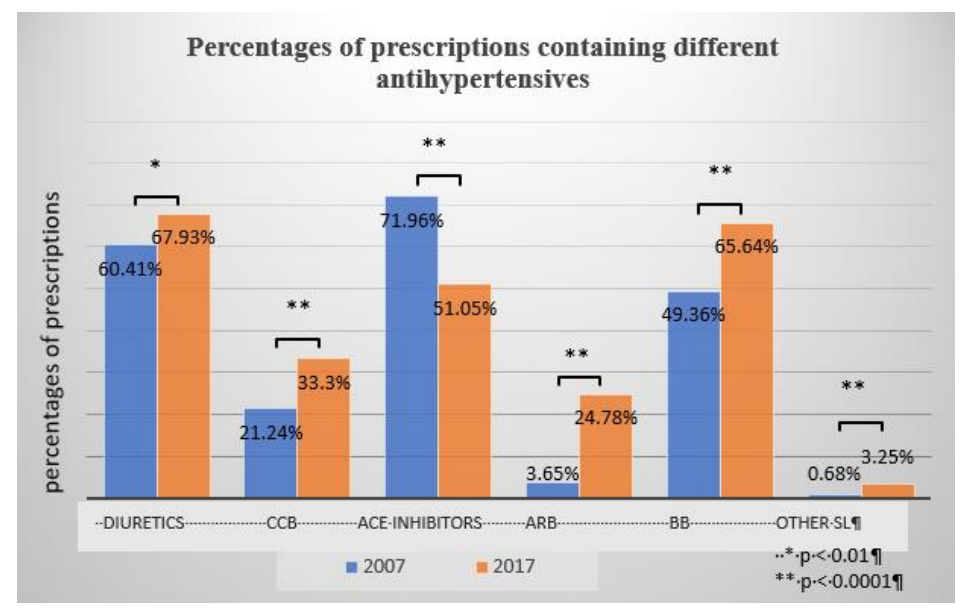

Figure 1.

Main antihypertensive therapeutic classes' changes (2017 versus 2007) (as percentages of prescriptions containing drugs from specified categories)

CCB - calcium channel blockers, ACE inhibitors - angiotensin converting enzyme inhibitors, ARB - angiotensin II receptor blockers, BB - beta blockers, SL - sympatholytics

Individual antihypertensive drugs' usage

At the level of evolution of the INNs, important changes have been observed, as shown in Table I.
The percentage changes refer to the absolute frequency of INNs prescription in their therapeutic class (column A) or in total antihypertensive prescriptions (column B).

Table I

Antihypertensive drugs' use in 2007 and 2017

\begin{tabular}{|c|c|c|c|c|}
\hline \multirow[b]{2}{*}{ INNs } & \multirow{2}{*}{$\begin{array}{c}2007 \\
\text { No. of } \\
\text { prescriptions }\end{array}$} & \multirow{2}{*}{$\begin{array}{c}2017 \\
\text { No. of } \\
\text { prescriptions }\end{array}$} & \multicolumn{2}{|c|}{ Percentages changes $(2017 \text { to } 2007)^{\mathrm{a}}$} \\
\hline & & & $\begin{array}{l}\text { Of INN use in its class } \\
\text { (column A) }\end{array}$ & $\begin{array}{l}\text { Of INN use in total antihypertensives } \\
\text { (column B) }\end{array}$ \\
\hline hydrochlorothiazide & 16 & 40 & $129.95 *$ & $158.57 * *$ \\
\hline indapamide & 608 & 555 & $-16.04 * *$ & -5.59 \\
\hline furosemide & 40 & 89 & $104.65 * *$ & $130.13 * *$ \\
\hline spironolactone & 47 & 89 & $74.17 *$ & $95.85 *$ \\
\hline Diuretics (total) & 711 & 773 & - & $12.45 *$ \\
\hline lercanidipine & 15 & 83 & $265.00 * *$ & $472.30 * *$ \\
\hline nifedipine & 37 & 7 & $-87.52 * *$ & $-80.43 * *$ \\
\hline amlodipine & 77 & 267 & $128.73 * *$ & $258.64 * *$ \\
\hline felodipine & 60 & 11 & $-87.91 * *$ & $-81.04 * *$ \\
\hline nitrendipine & 1 & 0 & -100 & $-100 *$ \\
\hline diltiazem & 28 & 7 & $-83.51 * *$ & $-74.14 *$ \\
\hline verapamil & 32 & 4 & $-91.75 * *$ & $-87.07 * *$ \\
\hline CCBs (total) & 250 & 379 & - & $56.80 * *$ \\
\hline captopril & 38 & 14 & $-46.29 *$ & $-61.90 *$ \\
\hline enalapril & 361 & 100 & $-59.62 * *$ & $-71.35 * *$ \\
\hline perindopril & 208 & 319 & $123.58 * *$ & $58.62 * *$ \\
\hline lisinopril & 58 & 18 & $-54.76 *$ & $-67.90 * *$ \\
\hline benazepril & 6 & 1 & -75.70 & -82.76 \\
\hline
\end{tabular}


FARMACIA, 2020, Vol. 68, 4

\begin{tabular}{|c|c|c|c|c|}
\hline \multirow[b]{2}{*}{ INNs } & \multirow{2}{*}{$\begin{array}{c}2007 \\
\text { No. of } \\
\text { prescriptions }\end{array}$} & \multirow{2}{*}{$\begin{array}{c}2017 \\
\text { No. of } \\
\text { prescriptions }\end{array}$} & \multicolumn{2}{|c|}{ 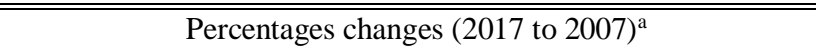 } \\
\hline & & & $\begin{array}{l}\text { Of INN use in its class } \\
(\text { column A) }\end{array}$ & $\begin{array}{l}\text { Of INN use in total antihypertensives } \\
\text { (column B) }\end{array}$ \\
\hline fosinopril & 69 & 23 & $-51.41 *$ & $-65.52 * *$ \\
\hline ramipril & 34 & 70 & $200.14 * *$ & $112.94 * *$ \\
\hline trandolapril & 16 & 9 & -18.00 & -41.82 \\
\hline quinapril & 48 & 7 & $-78.74 * *$ & $-84.92 * *$ \\
\hline zofenopril & 9 & 20 & $223.96 *$ & $129.84 *$ \\
\hline ECA-inhibitors (total) & 847 & 581 & - & $-29.05 * *$ \\
\hline candesartan & 0 & 164 & $* *$ & $* *$ \\
\hline irbesartan & 8 & 30 & -42.82 & $287.85 *$ \\
\hline losartan & 0 & 10 & & $*$ \\
\hline telmisartan & 23 & 39 & $-74.14 * *$ & $75.38 *$ \\
\hline valsartan & 12 & 29 & $-63.15 *$ & $149.95 *$ \\
\hline olmesartan & 0 & 10 & & $*$ \\
\hline ARBs (total) & 43 & 282 & - & $578.29 * *$ \\
\hline metoprolol & 416 & 463 & $-13.43 *$ & $15.11 *$ \\
\hline carvedilol & 39 & 44 & -12.25 & 16.69 \\
\hline nebivolol & 40 & 83 & $61.39 *$ & $114.61 * *$ \\
\hline betaxolol & 41 & 24 & $-54.47 *$ & $-39.46 *$ \\
\hline propranolol & 0 & 11 & $*$ & $*$ \\
\hline bisoprolol & 25 & 118 & $267.11 * *$ & $388.18 * *$ \\
\hline atenolol & 15 & 0 & $-100 * *$ & $-100 *$ \\
\hline sotalol & 5 & 4 & -37.78 & -17.26 \\
\hline BBs (total) & 581 & 747 & - & $32.98 * *$ \\
\hline methyldopa & 1 & 4 & -13.51 & 313.71 \\
\hline clonidine & 4 & 5 & $-72.97 *$ & 29.28 \\
\hline rilmenidine & 0 & 16 & $*$ & $* *$ \\
\hline moxonidine & 3 & 12 & -13.51 & $313.71 *$ \\
\hline Other SLs (total) & 8 & 37 & - & $378.35 * *$ \\
\hline Total prescriptions & 1177 & 1138 & & \\
\hline
\end{tabular}

${ }^{a}$ The percentage changes refer to the absolute frequency of INNs prescription in their therapeutic class (column A) or in total antihypertensive prescriptions (column B). * p < 0.01;** p < 0.0001. CCBs - calcium channel blockers; ACE inhibitors - angiotensin converting enzyme inhibitors; ARBs - angiotensin II receptor blockers; BBs - beta blockers; SLs - sympatholytics

Indapamide slightly decreased (-5.59\%), but remained the most prescribed diuretic: $85.51 \%$ of diuretics prescriptions in 2007 contained indapamide; the same happened with $71.8 \%$ of the prescriptions containing diuretic from 2017. The increasing use of furosemide, spironolactone and hydrochlorothiazide might be due to their frequent presence in fixed combinations. In both years amlodipine was the most commonly used calcium channel blockers (CCBs) $(30.80 \%$ in 2007 and $70.45 \%$ in 2017 , respectively), followed by felodipine in 2007 (24\%) or lercanidipine in 2017 (21.9\%).

In the ACE-inhibitors class and in the beta blockers (BBs) class, some INNs decreased in use and some INNs increased. All the ARBs and all the other sympatholytic then BBs (other SLs) raised in use. The most prescribed individual antihypertensive agents and their dynamics are displayed in Figure 2.

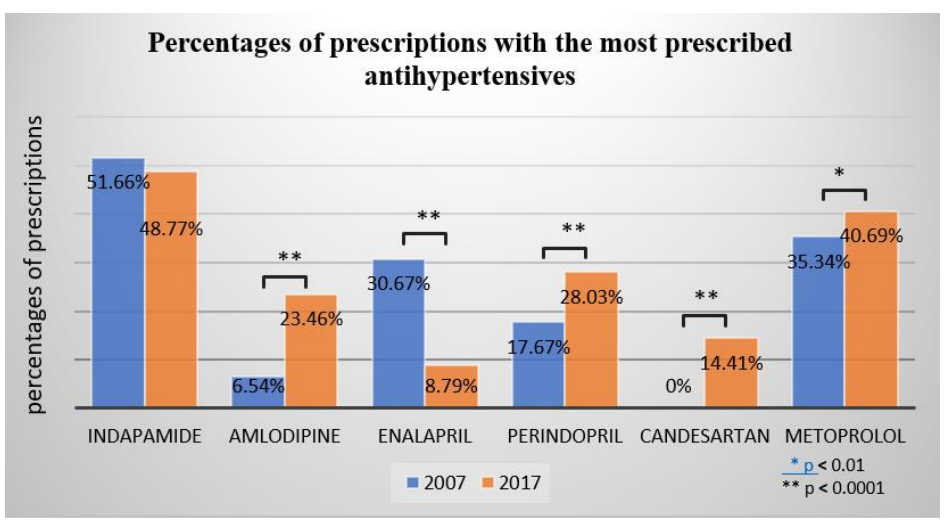

Figure 2.

Main antihypertensive agents' changes (2017 versus 2007) (as percentages of prescriptions containing particular drugs) 
Our results fitted widely accepted recommendations. The 2002 results of the ALLHAT study recommended the use of thiazide-like diuretics as first-line drugs to treat high blood pressure [2]. A systematic review from 2015 analysed 14 randomized clinical trials comparing the antihypertensive action and metabolic effects of hydrochlorothiazide with those of indapamide and chlorthalidone. The results showed a supplementary reduction in systolic blood pressure achieved by indapamide compared to hydrochlorothiazide and did not show significant differences in potassium metabolism [23].

Nonetheless, BBs are highly effective in preventing cardiovascular events in patients with a recent myocardial infarction and those with heart failure, and this feature could favour metoprolol massive use in the patients, who were suffering from more cardiovascular diseases, not only HBP [16].

Enalapril was the most used ACE-inhibitor in 2007, but perindopril exceeded it in 2017. Large-scale clinical trials have shown that perindopril-based treatments reduce morbidity and mortality in hypertensive patients, by reducing the risk of stroke and showing benefits in renal failure and diabetes when compared with other antihypertensive therapies [14]. Amlodipine showed a strong rise from 2007 to 2017, possible due to its antihypertensive efficacy. Amlodipine mediates vasodilatation through calcium channel blockage and through enhancement of nitric oxide production, with important improvement in endothelial functioning [13].

Candesartan was the most prescribed ARBs. This is worth noting, because in 2007 candesartan was not at all used.

Monotherapy versus combination therapy

The percentages of prescriptions containing monotherapy or multiple antihypertensive drugs combinations changed in the two years analysed. In 2007, bi-therapy was the most common, representing $41.29 \%$ of antihypertensive therapy, followed by monotherapy and tritherapy, each registering about $27 \%$; tetra- and pentatherapy were used in less than $5 \%$ of prescriptions. In 2017 , the highest percentages were reached by bitherapy (32.34\%) and tri-therapy (31.81\%), followed by monotherapy $(19.68 \%)$, tetra-therapy $(14.67 \%)$ and penta-therapy $(1.5 \%)$. We therefore observed a decreasing tendency of the use of mono- and bitherapy and an increase in the simultaneous use of three, four or five antihypertensive drugs; all these changes were statistically significant $(\mathrm{p}<0.01)$ (Figure 3). This was in accordance with the prescribing guidelines, which recommended the use of combination therapies, as more efficacious, and, if possible, in fixed combinations in order to increase medication adherence [18].

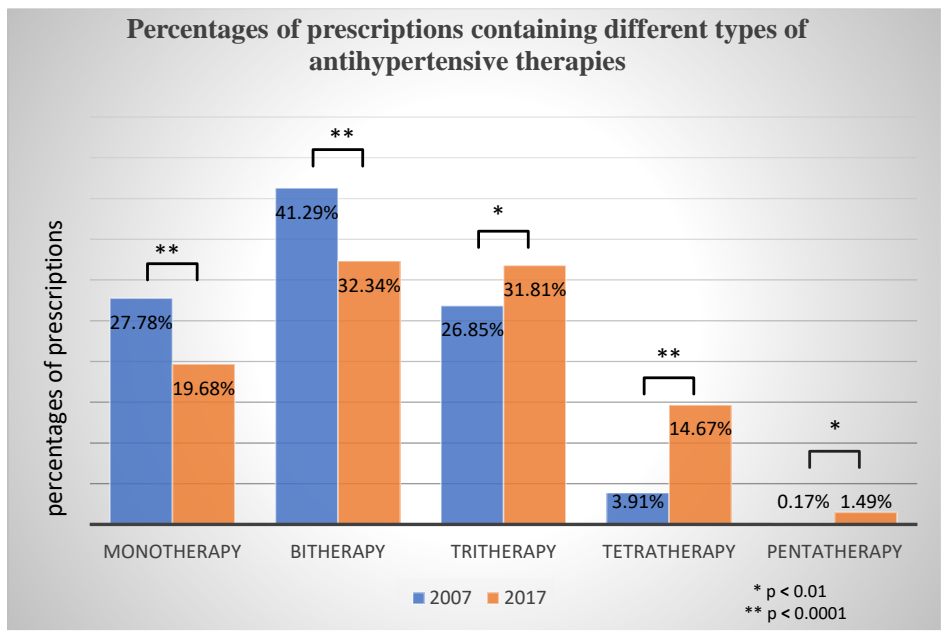

Figure 3.

Frequencies of monotherapy and combined therapies (2017 versus 2007)

The use of fixed combinations increased in 2017 by $363.63 \%$ compared to 2007. If in 2007 six types of fixed combinations between 2 antihypertensive substances were used, in 2017 twelve such combinations were used. Even more, in 2017 two fixed combinations associating 3 antihypertensives (perindopril + indapamide + amlodipine and amlodipine + valsartan + hydrochlorothiazide) appeared.

The most used fixed combinations in both analysed periods were the associations between perindopril and indapamide $(52.73 \%$ in 2007 and $50 \%$ in 2017), followed by that between spironolactone-furosemide (15\% in 2007 and $14 \%$ in 2017).

The comparative analysis of therapies in 2007 and 2017 revealed that:

The monotherapy was more frequently used in 2007 with ACE inhibitors (49.5\% of cases); in 2017, BBs (29.5\%) and ACE inhibitors (26.8\%) were the most used drugs in monotherapy.

The bi-therapy was most frequently used in 2007 with ACE inhibitors and diuretics (38.1\% of cases), followed by the combination of ACE inhibitors and BBs 
FARMACIA, 2020, Vol. 68, 4

(28\%), in 2017, the ranking changed, the combination of ACE inhibitors and BBs being the most frequently used $(27.2 \%)$, followed by the combination of ACE inhibitors and diuretics (21.5\%).

The tri-therapy most frequently used in 2007 contained ACE inhibitors, diuretics and BBs (59.8\% of cases); in 2017, the same association was the most common, but its percentage of use decreased (35.6\%), a much wider range of associations being used.

The tetra-therapy most commonly used in 2007 contained ACE inhibitors, diuretics, BBs and CCBs (54.3\% of cases); in 2017, the same association was the most common (51.5\%).

Antihypertensive treatment guidelines stressed the advantages of combination therapies, as they appeared in clinical studies and in meta-analysis as having better efficacy and tolerability. Combining any two agents from any two antihypertensives classes reduces the value of blood pressure more than increasing the dose of one medicine [26], causes fewer side-effects and has a fewer drop-out rate than monotherapy [7]. Drug related problems

$11.5 \%$ of the 2007 prescriptions and $18.6 \%$ of the 2017 prescriptions contained antihypertensive drugs prescribed in a more alert daily rhythm, compared to the one indicated in their officially endorsed monographs. These drugs were not necessarily overcoming the maximum allowed daily doses, but unnecessarily increased the number of pills to be administered on each day by a patient, with a possible negative consequence on medication adherence. We considered these to be drug related problems, requiring the intervention of the pharmacist, who could suggest sometimes medicines in a more concentrated form. Table II displays the antihypertensive drugs which were prescribed in more than $10 \%$ of their usage in the analysed period in an atypical manner, thus amplifying the medication regimen complexity.

Table II

Frequently used antihypertensive drugs, whose prescribing in more than necessary number of daily doses could negatively affect adherence to medication

\begin{tabular}{|l|c|c|c|c|}
\hline Antihypertensive agent & Usual regimen & Prescribed regimen & \multicolumn{2}{|c|}{$\begin{array}{c}\text { Atypical posology } \\
\text { (as \% of implied drug total prescription) }\end{array}$} \\
\cline { 4 - 5 } & & & 2007 & 2017 \\
\hline Amlodipine & once a day & twice a day & 10.39 & 4.49 \\
\hline Felodipine & once a day & twice a day & 28.33 & 9.64 \\
\hline Lisinopril & once a day & twice a day & 22.41 & 61.11 \\
\hline Fosinopril & once a day & twice a day & 27.54 & 43.48 \\
\hline Perindopril & once a day & twice a day & 6.82 & 15.67 \\
\hline Ramipril & once a day & twice a day & 2.94 & 14.29 \\
\hline Irbesartan & once a day & twice a day & 12.50 & 26.67 \\
\hline Candesartan & once a day & twice a day & NA & 10.00 \\
\hline Losartan & once a day & twice a day & 0 & 31.10 \\
\hline Bisoprolol & once a day & twice a day & 16.67 & 20.34 \\
\hline Betaxolol & once a day & twice a day & 12.20 & 0 \\
\hline
\end{tabular}

NA - not applicable

While antihypertensives prescribing guidelines highly recommend the use of long-acting medication, on a once-daily basis, which provide 24 hours efficacy $[12,18]$ (such as are all the drugs listed in Table II), the number of prescriptions containing unnecessarily too many daily doses increased from 2007 to 2017. We consider these results as being of paramount importance, pointing at a possible intervention for better adherence through drug regimen simplification by administering the entire daily dose once. Pharmacists should be involved in preventing such DRPs.

In 2007 we also noticed 8 prescriptions (0.67\%) containing two ACE-inhibitors. As the concomitant use of more ACE-inhibitors is not endorsed by clinical studies, we considered these prescriptions as inappropriate. Evidence about the disadvantages of the double blockade of renin-angiotensin-system [11, 29] had been acknowledged by Romanian prescribers till 2017, when no such combinations of drugs were found.

\section{Adherence to medication}

We quantified non-adherence to medication by the percentage of prescriptions not entirely dispensed, namely those situations when the patient didn't claim all the drugs prescribed by the physician. In 2007, $10.94 \%$ of hypertensive patients did not get all the medicines prescribed by the doctor from the pharmacy. In 2017, the percentage of these patients that we considered non-adherents amounted to $20.19 \%$.

As numerous studies showed, a significant cause of low hypertension control is the inadequate adherence to medication $[3,8,25]$. The patients that drop some or all of their antihypertensive drugs, such are those that did not fill their integral prescriptions, are at high risk of being non-adherent, and thus, possibly therapeutically uncontrolled. No antihypertensive drug, no matter how new $[9,20]$ or effective could be, is working in a patient that do not take it. 


\section{Study limitations}

This retrospective study collected data recommended on reimbursed prescriptions only from two community pharmacies from Bucharest, thus not reflecting the pattern of use. To see if the identified patterns are the same across the country, further studies are needed. Also, further studies are needed to investigate the tendency of prescribers to recommend medications in a more alert daily rhythm. Patients' reasons for not purchasing all the prescribed medicines should be supplementary evaluated.

\section{Conclusions}

The present paper compared the use of antihypertensive medications, as dispensed in the community pharmacies from the capital of Romania, Bucharest, in 2007 and 2017. We concluded that the use of antihypertensive medicines complied with HBP treatment guidelines regarding the type of drugs used but we identified a potential important DRP (unnecessary too complex drug regimen), with negative influence on medication adherence, which reached alarming levels in our study, being almost double in 2017 compared to 2007.

\section{Conflict of interest}

The authors declare no conflict of interest.

\section{References}

1. Abraham HMA, White CM, White WB, The comparative efficacy and safety of the angiotensin receptor blockers in the management of hypertension and other cardiovascular diseases. Drug Saf., 2015; 38(1): 33-54.

2. ALLHAT Officers and Coordinators for the ALLHAT Collaborative Research Group, The Antihypertensive and Lipid-Lowering Treatment to Prevent Heart Attack Trial. Major outcomes in high-risk hypertensive patients randomized to angiotensin-converting enzyme inhibitor or calcium channel blocker vs diuretic: The Antihypertensive and Lipid-Lowering Treatment to Prevent Heart Attack Trial (ALLHAT) [published correction appears in JAMA, 2003; 289(2): 178] [published correction appears in JAMA, 2004; 291(18): 2196]. JAMA. 2002; 288(23): 2981-2997.

3. Bradley HA, Wiysonge CS, Volmink JA, Mayosi BM, Opie LH, How strong is the evidence for use of beta-blockers as first-line therapy for hypertension? Systematic review and meta-analysis. J Hypertens., 2006; 24(11): 2131-2141.

4. Burnier M, Drug adherence in hypertension. Pharmacol Res., 2017; 125: 142-149.

5. National Centre of Studies for Family Medicine, Essential hypertension in adults: prevention, diagnostics and treatment. Practical guide for the family physician. Infomedica, Bucharest; 2005; 52-88, (available in Romanian)

6. Cipolle RJ, Strand L, Morley PC, Pharmaceutical care practice: the patient-centered approach to medication management services ( ${ }^{\text {rd }}$ Edition), Drug therapy problems. McGraw-Hill; 2012; 141-181.

7. Corrao G, Parodi A, Zambon A, Heiman F, Filippi A, Cricelli C, Merlino L, Mancia G, Reduced discontinuation of antihypertensive treatment by two-drug combination as first step. Evidence from daily life practice. $J$ Hypertens., 2010; 28(7): 1584-1590.

8. De Geest S, Ruppar T, Berben L, Schönfeld S, Hill MN, Medication non-adherence as a critical factor in the management of presumed resistant hypertension: A narrative review. EuroIntervention, 2014; 9(9): 11021109.

9. Diaconu CC, Drăgoi CM, Bratu OG, Neagu TP, Stoian AP, Cobelschi PC, Nicolae AC, Iancu MA, Hainăroșie R, Stănescu AMA, Socea B, New approaches and perspectives for the pharmacological treatment of arterial hypertension. Farmacia, 2018; 66(3): 408-415.

10. Dorobanţu M, Darabont R, Ghiorghe S, ArsenescuGeorgescu C, Macarie C, Mitu F, Lighezan D, Musetescu R, Pop C, Ardeleanu E, Craiu E, Tăutu OF, Hypertension prevalence and control in Romania at a seven-year interval. Comparison of SEPHAR I and II surveys. J Hypertens., 2014; 32(1): 39-47.

11. Esteras R, Perez-Gomez MV, Rodriguez-Osorio L, Ortiz A, Fernandez-Fernandez B, Combination use of medicines from two classes of renin-angiotensin system blocking agents: risk of hyperkalemia, hypotension, and impaired renal function. Ther Adv drug Saf., 2015; 6(4): 166-176.

12. European Society of Hypertension-European Society of Cardiology Guidelines Committee, 2003 European Society of Hypertension-European Society of Cardiology guidelines for the management of arterial hypertension. J Hypertens., 2003; 21(6): 1011-1053.

13. Fares H, DiNicolantonio JJ, O'Keefe JH, Lavie CJ, Amlodipine in hypertension: a first-line agent with efficacy for improving blood pressure and patient outcomes. Open Hear., 2016; 3(2): 1-7.

14. Fox K, Benefits of perindopril all along the cardiovascular continuum: the level of evidence. Eur Hear J Suppl., 2008; 10(Suppl G): G4-12.

15. Ingersoll $\mathrm{KS}$, Cohen $\mathrm{J}$, The impact of medication regimen factors on adherence to chronic treatment: A review of literature. J Behav Med., 2008; 31(3): 213-224.

16. Law MR, Morris JK, Wald NJ. Use of blood pressure lowering drugs in the prevention of cardiovascular disease: meta-analysis of 147 randomised trials in the context of expectations from prospective epidemiological studies. BMJ, 2009; 338: 1-19.

17. Mancia G, De Backer G, Dominiczak A, Cifkova R, Fagard R, Germano G, Grassi G, Heagerty AM, Kjeldsen SE, Laurent S, Narkiewicz K, Ruilope A, Schmieder RE, Struikjer Boudier HA, Zanchetti A, 2007 ESH-ESC Guidelines for the management of arterial hypertension. Blood Press, 2007; 16(3): 135-232.

18. Mancia G, Fagard R, Narkiewicz K, Redon J, Zanchetti A, Böhm M, Christiaens T, Cifkova R, De Backer G, Dominiczak A, Galderisi M, Grobbee DE, Jaarsma T, Kirchhof P, Kjeldsen SE, Laurent S, Manolis AJ, Nilsson PM, Ruilope ML, Schmieder RE, Sirnes PA, Sleight P, Viigimaa M, Waeber B, Zannad F, 2013 ESH/ESC guidelines for the management 
of arterial hypertension: the Task Force for the Management of Arterial Hypertension of the European Society of Hypertension (ESH) and of the European Society of Cardiology (ESC). Eur Heart J., 2013; 34(28): 2159-2219.

19. Marineci CD, Chiriță C, Văleanu A, Zbârcea CE, Negreș S, Sociodemographic factors' influence on adherence to antihypertensive medication. Farmacia, 2020; 68(2): 369-376.

20. Neamțu M, Rusu RN, Ababei DC, Bild W, Gavrilovici C, Stana B, Bild V, Molecular backgrounds of individualised pharmacotherapy. Farmacia, 2020; 68(3): 396-405.

21. Peacock E, Krousel-Wood M, Adherence to antihypertensive therapy. Med Clin North Am., 2017; 101(1): 229-245.

22. Pharmaceutical Care Network Europe, Classification for Drug related problems. 2003; www.pcne.org.

23. Roush GC, Ernst ME, Kostis JB, Tandon S, Sica DA, Head-to-head comparisons of hydrochlorothiazide with indapamide and chlorthalidone. Hypertension, 2015; 65(5): 1041-1046.
24. Tilea I, Petra D, Voidazan S, Ardeleanu E, Varga A, Treatment adherence among adult hypertensive patients: a cross-sectional retrospective study in primary care in Romania. Patient Prefer Adherence, 2018; 12: 625-635.

25. Vrijens B, Vincze G, Kristanto P, Urquhart J, Burnier $\mathrm{M}$, Adherence to prescribed antihypertensive drug treatments: Longitudinal study of electronically compiled dosing histories. BMJ, 2008; 336(7653): 1114-1117.

26. Wald DS, Law M, Morris JK, Bestwick JP, Wald NJ, Combination therapy versus monotherapy in reducing blood pressure: meta-analysis on 11,000 participants from 42 trials. Am J Med., 2009; 122(3): 290-300.

27. Wiysonge CS, Bradley HA, Volmink J, Mayosi BM, Mbewu A, Opie LH, Beta-blockers for hypertension. Cochrane database Syst Rev., 2012; 11: CD002003.

28. World Health Organization. Hypertension: Key Facts. 2019; www.who.int.

29. Yusuf S, Teo K, Pogue J, Dyal L, Copland I, Schumacher H, Dagenais G, Sleight P, Anderson C, Telmisartan, ramipril, or both in patients at high risk for vascular events. $N$ Engl J Med., 2008; 358(15): 1547-1559. 